\title{
Determination of soil specific surface area by water vapor adsorption I Drying of soil samples
}

\author{
RAINA NISKANEN ${ }^{1}$ and VÄINÖ MÄNTYLAHTI ${ }^{2}$ \\ I Department of Agricultural Chemistry, University of Helsinki, \\ SF-00710 Helsinki, Finland \\ 2 Viljavuuspalvelu Oy (Soil Analysis Service Ltd.), Vellikellontie 4, \\ SF-00410 Helsinki, Finland
}

\begin{abstract}
Drying of three mineral soil samples (clay content 4-58 \%, organic carbon content $1-5 \%$ ) equilibrated at $75.5 \%$ relative humidity was studied. The soils were dried in an oven at $+50^{\circ} \mathrm{C},+70^{\circ} \mathrm{C}$ and $+105^{\circ} \mathrm{C}$ for 4 and 8 hours and in a desiccator over pùre concentrated $\mathrm{H}_{2} \mathrm{SO}_{4}$ and $\mathrm{P}_{2} \mathrm{O}_{5}$. Drying over desiccants for 8 hours removed less water than drying at $+50^{\circ} \mathrm{C}$. Drying over desiccants for $3-7$ days was as efficient as drying at $+70^{\circ} \mathrm{C}$, for $14-24$ days as efficient as 4 hours of drying at $+105^{\circ} \mathrm{C}$. Eight hours of drying at $+105^{\circ} \mathrm{C}$ seemed to be too drastic, because it caused a greater weight loss in the clay sample of $5 \%$ organic carbon content than did prolonged desiccant-drying. Drying at $+70^{\circ} \mathrm{C}$ removed as much water from fine sand which contained $4 \%$ clay as prolonged desiccant-drying.
\end{abstract}

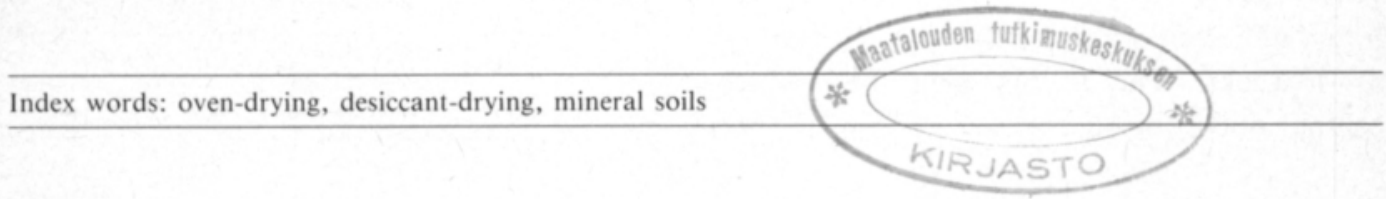

\section{Introduction}

High precision is needed in the determination of soil water content at high pF, e.g. in the estimation of soil specific surface area by water vapor adsorption. In such situations, the method often used for drying soil samples is equilibration in a desiccator over a desiccant like pure concentrated $\mathrm{H}_{2} \mathrm{SO}_{4}$ or $\mathrm{P}_{2} \mathrm{O}_{5}$ (e.g. ORCHISTON 1953, 1954, PRITCHARD, 1971, IWATA 1974). A highly hygroscopic desiccant removing the moisture in the air of a desiccator yields a relative humidity near zero. Drying is further enhanced by eva- cuation of the desiccator. However, a relatively long time may be needed for soils to reach constant weights. Equilibration may be accelerated by elevation of the drying temperature. Oven-drying is a common method for determination of water content. The aim of this study was to compare oven-drying and desiccant-drying in the determination of soil water content at high $\mathrm{pF}$.

\section{Material and methods}

The material consisted of three plough layer samples (Table 1) which were air-dried and 
Table 1. Soil samples.

\begin{tabular}{lcccc}
\hline $\begin{array}{l}\text { Soil } \\
\text { sample }\end{array}$ & $\begin{array}{c}\text { Org.C, } \\
\%\end{array}$ & \multicolumn{3}{c}{$\begin{array}{c}\text { Particle-size distribution } \\
(\mu \mathrm{m}), \%\end{array}$} \\
\cline { 3 - 5 } & & $<2$ & $2-20$ & $>20$ \\
\hline & & 4 & 10 & 86 \\
1 & 3.8 & 28 & 41 & 31 \\
2 & 1.1 & 58 & 14 & 28 \\
\hline
\end{tabular}

ground to pass a 2-mm sieve. The particle-size distribution of inorganic material was determined by the pipette method (ELONEN 1971) and organic carbon content by a modified (GraHAM 1948) ALTEN wet combustion method.

Soil, $1 \mathrm{~g}$, in a tared weighing bottle was placed in a desiccator over saturated $\mathrm{NaCl}$ solution at $75.5 \%$ relative humidity corresponding to pF 5.6 (BOLT and FrisSEL 1960). After two weeks of equilibration at $+20^{\circ} \mathrm{C}$ the soil + weighing bottle was weighed. Parallel samples were dried in an oven or over $\mathrm{H}_{2} \mathrm{SO}_{4}$ or $\mathrm{P}_{2} \mathrm{O}_{5}$. In oven-drying, the temperatures were $+50^{\circ} \mathrm{C},+70^{\circ} \mathrm{C}$ and $+105^{\circ} \mathrm{C}$. The samples were dried for 4 hours, weighed, dried for another 4 hours and reweighed. In the desiccator, the samples were dried over pure concentrated $\mathrm{H}_{2} \mathrm{SO}_{4}$ or $\mathrm{P}_{2} \mathrm{O}_{5}$ and weighed after 8 hours and then occasionally over a period of 3-4 weeks. The drying procedures were carried out in duplicate.

\section{Results and discussion}

When the soils were oven-dried at $+50^{\circ} \mathrm{C}$, prolongation of drying time from 4 to 8 hours increased the moisture percentage of clay soil No. 3 only (Table 2). Elevation of drying temperature to $+70^{\circ} \mathrm{C}$ increased the moisture percentage of all soils. Prolongation of drying time to 8 hours at $+70^{\circ} \mathrm{C}$ increased the moisture percentage of fine sand sample No. 1. Elevation of drying temperature to $+105^{\circ} \mathrm{C}$ no more increased the moisture percentage of this coarse soil, while the moisture percentage of the other soils increased. Prolongation of drying time to 8 hours at $+105^{\circ} \mathrm{C}$ increased the moisture percentage of clay soil No. 3 which had the highest organic carbon content.

Drying over $\mathrm{H}_{2} \mathrm{SO}_{4}$ or $\mathrm{P}_{2} \mathrm{O}_{5}$ for 8 hours removed less water than drying at $+50^{\circ} \mathrm{C}$ (Table 2). Drying over $\mathrm{P}_{2} \mathrm{O}_{5}$ for 8 hours removed more water from soil No. 3 than drying over $\mathrm{H}_{2} \mathrm{SO}_{4}$ for 8 hours. Drying in a desiccator for 3-7 days was as efficient as drying at $+70^{\circ} \mathrm{C}$. Desiccant-drying for $14-24$ days was as efficient as 4 hours of drying at $+105^{\circ} \mathrm{C}$. Eight hours of drying at $+105^{\circ} \mathrm{C}$ increased the moisture percentage of soil No. 3 more than prolonged drying in a desiccator.

The most frequently used definition for a dry soil is the mass of a soil sample after it has come to constant weight in an oven at a temperature between $+100^{\circ} \mathrm{C}$ and $+110^{\circ} \mathrm{C}$ (GARDNER 1965, BAVER et al. 1972). However, there exists no unique temperature at which different soil minerals can be heated to drive off all adsorbed water and leave behind only the water of crystallization. Such drying temperatures range from $+100^{\circ} \mathrm{C}$ to over $+400^{\circ} \mathrm{C}$. Organic materials may oxidize at temperatures as low as $+50^{\circ} \mathrm{C}$ (GARDNER 1965, BAVER et al. 1972).

Table 2. Moisture percentages after drying.

\begin{tabular}{|c|c|c|c|c|}
\hline \multirow{2}{*}{$\begin{array}{l}\text { Drying } \\
\text { method }\end{array}$} & \multirow{2}{*}{$\begin{array}{l}\text { Drying } \\
\text { time }\end{array}$} & \multicolumn{3}{|c|}{$\mathrm{H}_{2} \mathrm{O} \%$ of dry soil } \\
\hline & & Soil 1 & Soil 2 & Soil 3 \\
\hline \multirow[t]{2}{*}{$50^{\circ} \mathrm{C}$} & $4 \mathrm{~h}$ & $1.25^{\mathrm{b}}$ & $2.02^{\mathrm{b}}$ & $2.95^{c}$ \\
\hline & $8 \mathrm{~h}$ & $1.34^{b}$ & $1.90^{b}$ & $3.11^{\mathrm{d}}$ \\
\hline \multirow[t]{2}{*}{$70^{\circ} \mathrm{C}$} & $4 \mathrm{~h}$ & $1.58^{\mathrm{c}}$ & $2.35^{\mathrm{c}}$ & $3.90^{f g}$ \\
\hline & $8 \mathrm{~h}$ & $2.01^{\mathrm{fg}}$ & $2.49^{\mathrm{cd}}$ & $3.64^{e}$ \\
\hline \multirow[t]{2}{*}{$105^{\circ} \mathrm{C}$} & $4 \mathrm{~h}$ & $1.96^{\mathrm{efg}}$ & $2.94^{x}$ & $4.17^{i j}$ \\
\hline & $8 \mathrm{~h}$ & $2.06^{8}$ & $2.88^{\mathrm{fg}}$ & $4.74^{k}$ \\
\hline \multirow[t]{6}{*}{$\mathrm{H}_{2} \mathrm{SO}_{4}$} & $8 \mathrm{~h}$ & $0.87^{a}$ & $1.43^{\mathrm{a}}$ & $2.06^{a}$ \\
\hline & $3 \mathrm{~d}$ & $1.68^{\mathrm{cd}}$ & $2.50^{\mathrm{cd}}$ & $3.73^{e}$ \\
\hline & $7 \mathrm{~d}$ & $1.78^{\text {cdef }}$ & $2.64^{\mathrm{de}}$ & $3.97 \mathrm{gh}^{-1}$ \\
\hline & $10 \mathrm{~d}$ & $1.77^{\text {cdef }}$ & $2.64^{\text {de }}$ & $3.97^{\mathrm{gh}}$ \\
\hline & $17 \mathrm{~d}$ & $1.88^{\mathrm{defg}}$ & $2.77^{\mathrm{efg}}$ & $4.13^{i j}$ \\
\hline & $21 \mathrm{~d}$ & $1.85^{\mathrm{defg}}$ & $2.70^{\text {ef }}$ & $4.05^{\text {ehi }}$ \\
\hline \multirow[t]{7}{*}{$\mathrm{P}_{2} \mathrm{O}_{5}$} & $8 \mathrm{~h}$ & $1.00^{\mathrm{a}}$ & $1.52^{\mathrm{a}}$ & $2.22^{\mathrm{b}}$ \\
\hline & $3 \mathrm{~d}$ & $1.73^{\text {cde }}$ & $2.50^{\mathrm{cd}}$ & $3.75^{\text {ef }}$ \\
\hline & $7 d$ & $1.89 \mathrm{defg}$ & $2.65^{\mathrm{de}}$ & $3.97^{\mathrm{gh}}$ \\
\hline & $10 \mathrm{~d}$ & $1.89^{\mathrm{defg}}$ & $2.64^{\mathrm{de}}$ & $3.97 \mathrm{gh}^{\mathrm{h}}$ \\
\hline & $14 \mathrm{~d}$ & $1.92^{\text {defg }}$ & $2.70^{\mathrm{ef}}$ & $4.03^{\text {ghi }}$ \\
\hline & $24 \mathrm{~d}$ & $2.03 \mathrm{~s}$ & $2.83^{\mathrm{rg}}$ & $4.21^{i}$ \\
\hline & $28 \mathrm{~d}$ & $1.99^{\mathrm{fg}}$ & $2.73^{\mathrm{ef}}$ & $4.10^{\text {hij }}$ \\
\hline
\end{tabular}

Soils tested separately 
The non-colloidal particles have a small quantity of adsorbed water which is easily removed from their surfaces by heating (GARDNER 1965). Soil No. 1, representing soils of low clay content, seemed to be dried at a temperature as low as $+70^{\circ} \mathrm{C}$. Water present in the clay fraction may be considered in two categories, structural and adsorbed water, and it is often difficult to distinguish between the two (GARDNER 1965).

In desiccant-drying, soil organic matter is not decomposed and lost from the sample.

\section{References}

Baver, L.D., Gardner, W.H. \& Gardner, W.R. 1972. Soil physics. 4th edition. 498 p. New York.

Bolt, G.H. \& Frissel, M.J. 1960. Thermodynamics of soil moisture. Neth. J. Agr. Sci. 8: 57-78.

Elonen, P. 1971. Particle-size analysis of soil. Acta Agr. Fenn. 122: 1-122.

Gardner, W.H. 1965. Water content. Agronomy 9, 1: $82-127$.

Graham, E. 1948. Determination of soil organic matter by means of a photoelectric colorimeter. Soil Sci. 65 : $181-183$.

IWATA, S. 1974. Thermodynamics of soil water: IV.

\section{SELOSTUS}

\section{Maan ominaispinta-alan määrittäminen vesihöyryn adsorption avulla}

\section{Maanäytteiden kuivausmenetelmien vertailu}

\author{
Raina Niskanen ${ }^{1}$ ja Väinö Mäntylahti ${ }^{2}$ \\ 1 Maanviljelyskemian laitos, Helsingin yliopisto, 00710 \\ Helsinki \\ 2 Viljavuuspalvelu Oy, Vellikellontie 4, $00410 \mathrm{Helsinki}$
}

Kolmella kivennäismaanäytteellä (saves- $\%$ 4-58, org. C-\% 1-5), jotka oli tasapainotettu 75,5 prosentin suhteellisessa kosteudessa, verrattiin kuivatusta lämpökaapissa ja kuivausaineiden avulla. Maanăytteită kuivattiin lämpökaapissa lămpötiloissa $50^{\circ} \mathrm{C}, 70^{\circ} \mathrm{C}$ ja $105^{\circ} \mathrm{C}$ neljän ja kahdeksan tunnin ajan ja eksikkaattoreissa puhtaan väkevăn rikkihapon ja fosforipentoksidin avulla. Kuivausaineet poistivat kahdeksassa tunnissa vähemmän vettä kuin kuivaus $50^{\circ} \mathrm{C}$ :ssa. Kuivausaineet poistivat 3-7
Oven-drying with prolonged heating can remove structural water or cause decomposition of organic matter. Four hours of drying at $+105^{\circ} \mathrm{C}$ seemed to be sufficient, moisture percentage did not significantly deviate from those obtained by prolonged desiccant-drying. Eight hours of drying at $+105^{\circ} \mathrm{C}$ was possibly too drastic, because it caused additional weight loss in sample No. 3 of about $5 \%$ organic carbon content. It is possible that some decomposition of soil organic matter has occurred.

Chemical potential of soil water. Soil Sci. 117: 135-139.

OrChiston, H.D. 1953. Adsorption of water vapor: I, Soils at $25^{\circ} \mathrm{C}$. Soil Sci. 76: $453-465$.

-1954 . Adsorption of water vapor: II. Clays at $25^{\circ} \mathrm{C}$. Soil Sci. 78: 463-480.

Pritchard, D.T. 1971. Aluminium distribution in soils in relation to surface area and cation exchange capacity. Geoderma 5:255-260.

Ms received March 18, 1987 päivässä yhtă paljon vettă kuin haihtui $70^{\circ} \mathrm{C}$ :ssa ja $14-24$ păivăssă yhtă paljon kuin poistui neljän tunnin kuivauksessa $105^{\circ} \mathrm{C}$ :ssa. Kahdeksan tunnin kuivaus $105^{\circ} \mathrm{C}$ :ssa vaikutti liian tehokkaalta, koska savimaanăyte, joka sisälsi $5 \%$ orgaanista hiiltä, keveni enemmän kuin pitkässä kuivauksessa kuivausaineilla. Toisaalta $4 \%$ savesta sisăltăvălle hietamaanäytteelle kuivaus $70^{\circ} \mathrm{C}$ :ssa oli riittăvă poistamaan yhtä paljon vettả kuin pitkă kuivaus kuivausaineilla. 